\title{
Waste to Electricity Generation in Thailand: Technology, Policy, Generation Cost, and Incentives of Investment
}

\author{
PrachuabPeerapong $^{\mathrm{a}}$, and Bundit Limmeechokchai ${ }^{\mathrm{b}}$ \\ Sirindhorn International Institute of Technology, Thammasat University, Klongluang, PrathumThani, \\ 12121, Thailand \\ E-mail: aprachuab@siit.tu.ac.th, bbundit@siit.tu.ac.th (Corresponding author)
}

\begin{abstract}
Waste-to-Energy is a challenging management in developing countries. There are many different technologies to generate electricity or heat from wastes. However, reuse and recycling are first prioritized as left a fraction of waste can be used as energy recovery. The initial cost to generate electricity from solid waste incineration is prohibitively high due to its cost of advance technology and the cost of equipment to control emissions. Thailand is agricultural based country and has experiences of many technologies to utilize waste to energy. Landfill gas and thermal gasification are increasingly interesting alternatives to municipal solid waste incineration and it is recommended that biogas technology is suitable and is cost effective in management of organic waste or animal manure waste. This research studied in existing technologies in terms of electricity generated from waste, long term government policy, carbon dioxide reduction, electricity cost production and incentive investment. Until recently, Thailand has generated electricity from waste of $47 \mathrm{MW}$, from the target in 2021 with target capacity of 400 MW. Since Thailand has an incentive investment of electric power generated from renewable sources and wastes in terms of feed-in tariffs it can motivate private investors to invest and produce electricity to the grid. To generate electricity from waste it also has potential in reducing $\mathrm{CO}_{2}$ reduction and creates more potential jobs. In various agricultural based industries such as palm oil industry, cassava industry, in animal farm and in landfills gas have potential to generate electricity in Thailand. In case of landfill gas with the installed capacity of 3.0 MW, it can generate electricity of $13,492 \mathrm{MWh}$ per year and produce potential of selling carbon credits of 60,532 ton- $\mathrm{CO}_{2}$ per year.
\end{abstract}

Keywords: Waste-to-energy, organic waste and landfills gas, feed-in tariffs, electricity generation.

ENGINEERING JOURNAL Volume 20 Issue 4

Received 3 March 2016

Accepted 13 June 2016

Published 1 August 2016

Online at http://www.engj.org/

DOI:10.4186/ej.2016.20.4.171 


\section{Introduction}

Electricity consumption in Thailand in 2013 was about 164,341 GWh in all sectors; in the residential sector:37,657 GWh, in small general service sector: 18,374 GWh, in business sector: 30,413 GWh, in industry sector: 72,536 GWh, in government usage and non-profit: $149 \mathrm{GWh}$, in agriculture sector: 354 GWh, other uses: $2479 \mathrm{GWh}$ and free of charge: $2379 \mathrm{GWh}$. Total fuel consumption for electricity generation comes fromnatural gas: 412,701.72 million cubic feet, fuel oil: 316.82 million liters, lignite: 16.88 million tons, and diesel oil: 60.35 million liters. Electricity demand has beenincreasingannually, and forecasted that it will increase to 346,767 GWh in 2030 [1].The Ministry of Energy has come up with a policy to develop the renewable energy (RE) and released the Alternative Energy Development Plan (AEDP) for a ten-year period (2012-2021) [2]. In 2012, the objective of AEDP is to increase the portfolio of renewable energy to $25 \%$ of the final energy consumption in 2021. However the updated AEDP in 2015 called AEDP 2015-2036 is aiming to increase share of renewable energy penetration in electricity generation in Thailand to $30 \%$, which is equivalent to $19,635 \mathrm{MW}$ by 2036, the AEDP plan is expected to be integrated renewable energy in electricity generation increasing from 4,279 MW at the end of 2014 to 19,635 MW in 2036. Since Thailand is an agricultural-based country and high solar irradiation potential, the sources of renewable capacity are highly projected to solar power (6,000 MW), and followed with biomass (5,570 MW), hydro power (3,282 MW), wind power (3,002 MW), biogas (600 MW), municipal solid waste (501 MW), and electricity from energy crop (680 MW). The energy target for biogas and municipal solid waste is a challenging energy management of a sustainable development for Thai government. The new scheme of feed-in tariffs in 2015 for waste (landfill gas) is $5.60 \mathrm{Baht} / \mathrm{kWh}$ with the subsidiary of 10 years, and feed-in tariffs for biogas (from wastewater/waste products) is $3.76 \mathrm{Baht} / \mathrm{kWh}$ with the subsidiary for 20 years.

\section{Methodology}

The methodology is developed for analyzing the potential processes for converting waste, MSW and organic waste streams into the valuable energy products and electricity generation with any types of energy conversions with considering in electricity cost production and carbon dioxide reduction potential.The methodology of calculation of emissions and electricity in this study is based on Clean Development Mechanism (CDM) methodology in order to determine the amount of Certified Emission Reductions (CERs) generated by CDM projects in UNFCCC [3]. The levelised electricity product cost in projects is a key determination of renewable feasibility investment.The LCOE is commonly used to compare the cost of energy generated by a renewable resource with that of a standard fossil-fueled generatingunit[4].The levelised cost is the real cost of supplying electricity that if recovered from consumers over the lifetime of the plant would meet all costs associated with construction, operation and decommissioning of a generating plant.The mathematical relationship for the levelised cost of electricity is defined as in Eq. (1).

$$
\operatorname{LCOE}=\frac{\left.\sum_{n=0}^{N}\left(C_{n} /(1+r)^{n}\right)\right)}{\sum_{n=0}^{N}\left(\left(Y_{n} /(1+r)^{n}\right)\right.}
$$

where $C_{n}$ represents the cost for time period $n$ and $Y_{n}$ is the electricity yield during time period $n$, years. All capital costs are upfront costs and are thus not discounted and assumed to occur in the initial period. Operating costs and electricity yield (in $\mathrm{kWh}$ ) are incurred during time periods 1 to $\mathrm{N}$. These values are discounted and summed subject to the discount rate $r$. The discounted and summed value of lifetime cost from time period 0 to time period $\mathrm{N}$ (year) is then divided by the discounted and summed electricity yield to calculate the LCOE. In this study, the lifetime of all projects is 20 years and the discounted rate is given as $8 \%$. The capital cost, operating cost and maintenance cost of the projects are accessed in CDM project in UNFCCC [3].

\section{Technology Descriptions}

\subsection{Anaerobic Digestion}

Anaerobic digestion uses micro-organisms to break down biodegradable material into methane and carbon dioxide, with a slurry digestion co-product. The process begins with waste pre-treatment including waste 
sorting, size reduction and moisture content adjusting. These pre-treatment processes will affect process yield and biogas quality, which is generally effect onorganic wastes to energy technologies. The microbial reactions of anaerobic digestion include the hydrolysis of polysaccharides, proteins, and lipids into sugars and amino acids. The reaction can be accomplished in either batch or continuous systems, at either mesospheric condition $\left(20-40^{\circ} \mathrm{C}\right)$ or either thermophilic condition $\left(50-65^{\circ} \mathrm{C}\right)$. Biogas from anaerobic digestion can be cleaned and upgraded before use. Cleaning biogas process is to remove hydrogen sulfide, water, and particles; and the upgraded biogas process is to remove $\mathrm{CO}_{2}[5]$.

\subsection{Fermentation}

Fermentation is a process which microorganisms propagate on a growth medium that with the results of production of $\mathrm{CO}_{2}$ and alcohol and other carboxylates products (acids, esters, and salts). A common growth medium for fermentation is sugar which bacteria and yeast cells use to increase in numbersand produce these carboxylates products [6].

\subsection{Gasification}

Gasification is a process that converts waste into syngas. The syngas is a mixture of hydrogen, carbon monoxide via partial oxidation process. This process needs high temperatures between $550-1600{ }^{\circ} \mathrm{C}$ depending on process design and operating parameters. The process called refuse derived fuel (RFD) is the most gasification process that is pretreated wasteby size reduction. Three types of equipment are applied in waste gasification: fixed-bed gasifiers, entrained-flow gasifiers, and fluidized-bed gasifiers [7].

\subsection{Incineration}

Incineration of waste is a mass burn technology, performing with a controlled combustion. Waste is placed on a grate that transverse the combustor with excess air supplying to typically combust up to 1,000 metric tonne a day. The air is controlled ranging between the highlevels and the low levels. The high level iswhich lower the burn temperatures and reaction rates, while the low level is which could allow hydrocarbons to exit unburned. The electricity and steam are generated by combustors [8].

\section{Organic Waste for Cases of Electricity Production in Thailand}

\subsection{Landfill Gas to Electricity}

Landfill gas (LFG) to electricityis aprocess that capturesgas and utilizes to generate electricity in the gas engine generators, in Fig. 1.

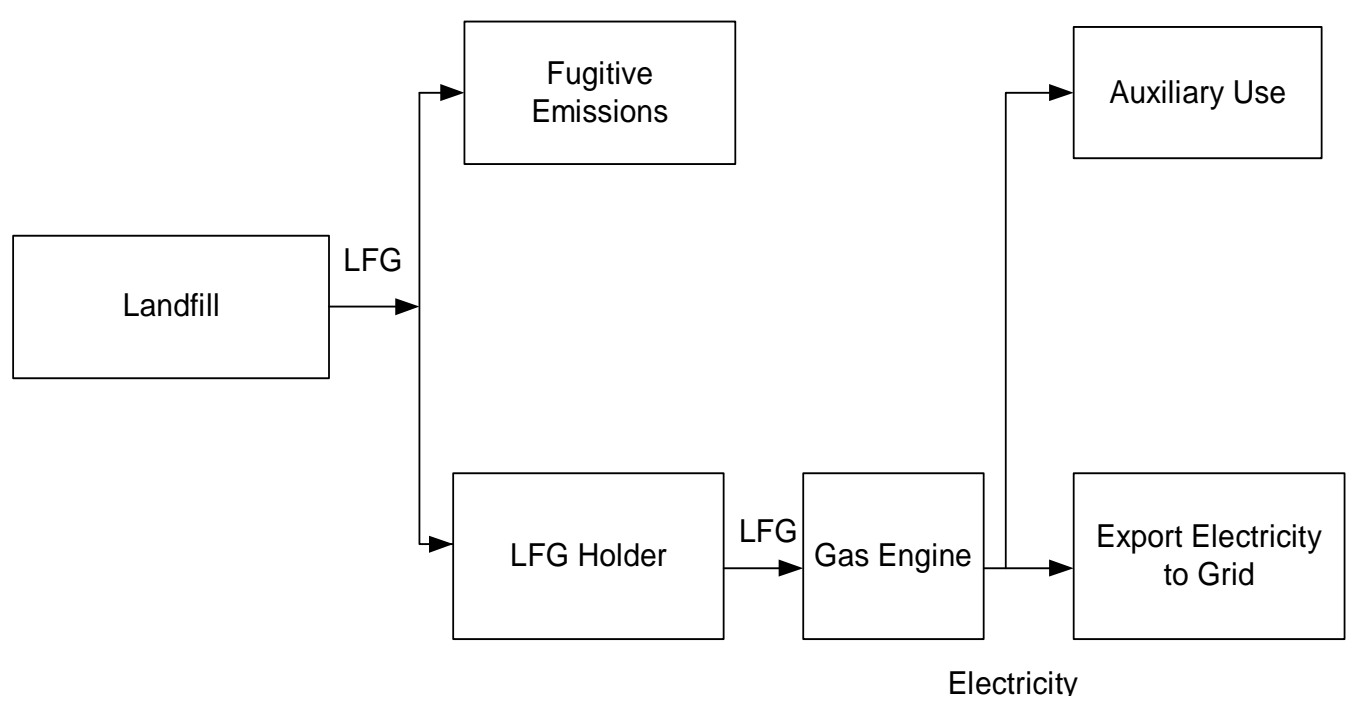

Fig. 1. Schematic diagram of electricity generation from landfill gas. 
The LFG will be channelled to a gas collecting vessel (balloon type) to be stored rather than flaring it. This will minimize the methane emission to the atmosphere and maximise carbon emission reduction. The project will reduce thecarbonemissions by utilizing the captured LFG that otherwise releases to the atmosphere and by displacing the grid electricity by electricity generated from the LFG. Detailed data in landfill gas are shown in Table 1.

Table 1. Detailed characteristics in landfill gas for electricity generation.

\begin{tabular}{lccr}
\hline Item & Values & Unit & Sources \\
\hline Electricity capacity & 3,000 & $\mathrm{~kW}$ & Data from manufacturer \\
Plant capacity factor & 51 & $\%$ & Calculation \\
Electricity generation & 13,492 & $\mathrm{MWh} / \mathrm{yr}$ & Calculation \\
Gas engine efficiency & 40 & $\%$ & Data from manufacturer \\
\hline
\end{tabular}

\subsection{Palm Oil Wastewater Biogas to Electricity}

The palm oil mill process uses to the generation of wastewater, in Fig. 2.

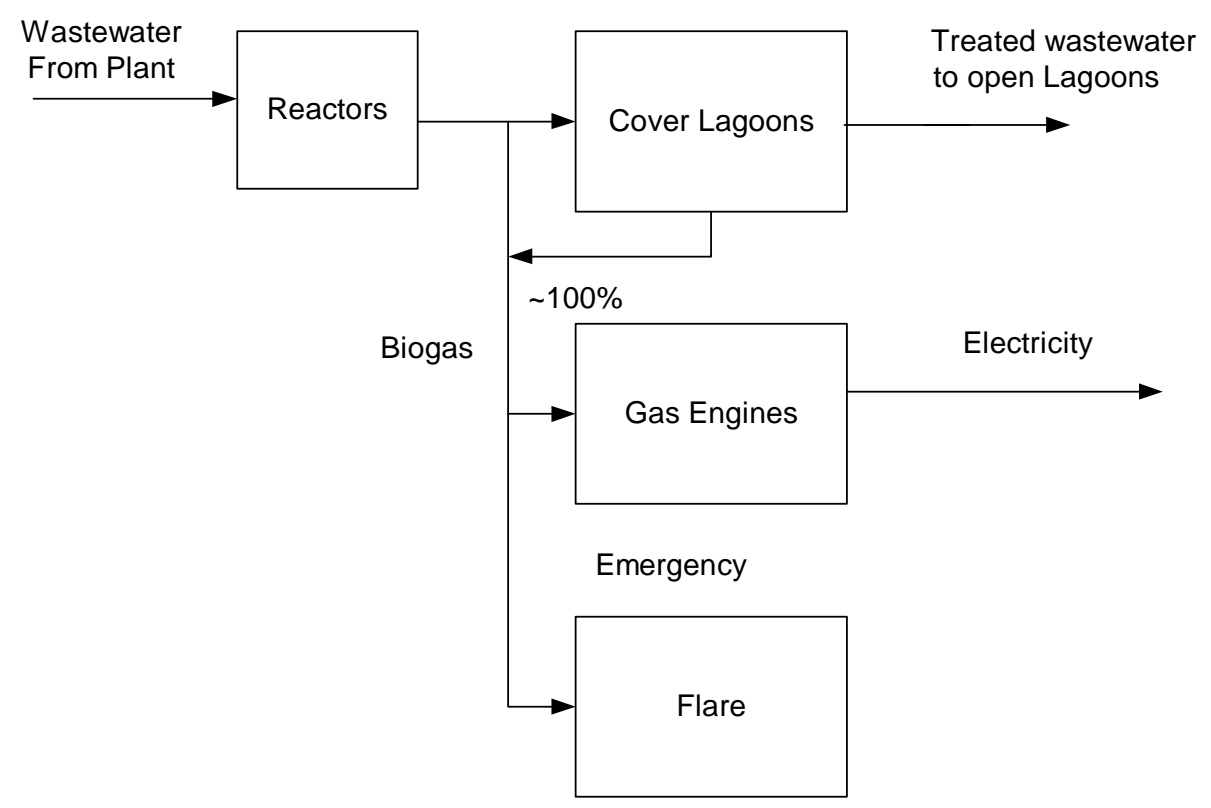

Fig. 2. Schematic diagram of electricity generation from wastewater.

The project activity involves introduction of a new wastewater treatment system, using a Completely Stirred Tank Reactor (CSTR) technology to treat wastewater from an existing crude palm oil extraction mill. Subsequently to the treatment of waste water in the CSTR, the water will run to the of the existing open lagoon system, which will serve as post treatment and water reservoir. The CSTR system will hence enable capturing and utilisation of methane, which otherwise would be emitted directly in to the atmosphere.The captured methane (from biogas) will be fuelled to gas engines that run generators that produce electricity. The gross installed capacity of the gas engine generator of $1,000 \mathrm{~kW}$. The project activity will primarily help to reduce the amount of methane released into the atmosphere, which otherwise would be emitted from the open lagoon system. Technical data in palm oil power plantare shown in Table 2.

Table 2. Detailed characteristics in palm oil power plant.

\begin{tabular}{lccl}
\hline Item & Values & Unit & Sources \\
\hline Volume of wastewater & 259 & $\mathrm{~m}^{3} /$ day & Data from the project owner \\
Operating day & 300 & days $/$ year & Data from the project owner \\
COD of wastewater & 0.076811 & Ton $/ \mathrm{m}^{3}$ & Data from the project owner
\end{tabular}




\begin{tabular}{|c|c|c|c|}
\hline Electricity capacity & 1,000 & $\mathrm{~kW}$ & Data from manufacturer \\
\hline Electricity generation & 2,999 & MWh/yr & Calculation \\
\hline Electricity generation rate & 2.08 & $\mathrm{kWh} / \mathrm{m}^{3}$ & $\begin{array}{r}\text { Data from manufacturer } \\
\text { at } 60 \% \mathrm{CH}_{4} \text { in biogas }\end{array}$ \\
\hline Electricity efficiency & 40 & $\%$ & Data from manufacturer \\
\hline
\end{tabular}

\subsection{Cassava Wastewater Biogas to Electricity}

Wastewater exiting in the tapioca starch production facility first passes through a pre-treatment pond, which reduces the wastewater acidity to render it, is suitable for processing in the Up flow Anaerobic Sludge Blanket (UASB) system, an anaerobic bioreactor technology.The utilization of this advanced technology, the project will be able to achieve $90 \%$ removal of COD, significantly reducing the COD load to the open lagoons. While wastewater comes in contact with the granules, anaerobic decomposition of the organic material contained in the wastewater takes place, resulting in the generation of methane-rich biogas. Detailed data in cassava power plant are shown in Table 3.

Table 3. Detailed characteristics in cassava power plant.

\begin{tabular}{lccr}
\hline Item & Values & Unit & Sources \\
\hline Volume of wastewater & 9,000 & $\mathrm{~m}^{3} /$ day & Data from the project owner \\
Operating day & 300 & days/year & Data from the project owner \\
COD of the wastewater & 12,000 & $\mathrm{mg} /$ liter & Data from the project owner \\
Electricity capacity & 4,800 & $\mathrm{~kW}$ & Data from manufacturer \\
Electricity generation & 13,705 & $\mathrm{MWh} / \mathrm{yr}$ & Calculation \\
Electricity efficiency & 40 & $\%$ & Data from manufacturer \\
\hline
\end{tabular}

\subsection{Swine Farm Wastewater Biogas to Electricity}

With a current swine rearing capacity of 70,000 fattening swine, this project applies the high-rate anaerobic wastewater treatment reactors used in the project, based on the high suspended solids Up flow Anaerobic Sludge Blanket (H-UASB) system.This system allows the majority of enzymatic breakdown of the solids fraction to occur in isolation from the other main steps of the anaerobic digestion process.Biogas from the H-UASB treatment plants is captured and stored in digester tank, then there is piped to the $480 \mathrm{~kW}$ biogas electricity generation sets. The electrical power will be replaced that was previously bought-in from the Thai electricity grid. And consequently from setting the system, any excess electricity will be exported to the national grid.This project leads to a reduction in anthropogenic GHG emissionsthat estimated GHG emissions of 23,556 tonnes carbon dioxide equivalent per year. Detailed data in swine farm are shown in Table 4.

Table 4. Detailed characteristics in swine farm.

\begin{tabular}{lccr}
\hline Item & Values & Unit & Sources \\
\hline Swine population & 70,000 & heads & Data from the project owner \\
Biogas generation & $2,735,815$ & $\mathrm{~m}^{3} /$ year & Data from the project owner \\
Daily energy intake & 26.2 & $\mathrm{MJ} / \mathrm{head}$ & Data from the project owner \\
Annual methane capture & 1,191 & Ton $/$ year & Data from the project owner \\
Methane density & 0.67 & $\mathrm{~kg} / \mathrm{m}^{3}$ & Data from the project owner \\
Methane content & 65 & $\%$ & Data from the project owner \\
Daily biogas off take & 7,495 & $\mathrm{~m}^{3} / \mathrm{day}$ & Calculation \\
Electricity capacity & 480 & $\mathrm{~kW}$ & Data from manufacturer \\
Electricity generation & 2,736 & $\mathrm{MWh} / \mathrm{yr}$ & Calculation \\
Electricity generation rate & 1.00 & $\mathrm{kWh} / \mathrm{m}^{3}$ & Calculation \\
Electricity efficiency & 40 & $\%$ & Data from manufacturer \\
\hline
\end{tabular}




\section{Results and Discussion}

In this study the electricity generation from wastewater from palm oil plant, cassava plant, swine farm and from landfill gas was investigated. The results show that: i)the landfill gas with gas engine capacity of 3000 $\mathrm{kW}$ can generate $13,492 \mathrm{MWh}$ of electricity per year at electricity product cost of $0.115 \$ / \mathrm{kWh}$, resulting in $\mathrm{CO}_{2}$ reduction of 60,532 ton per year, ii) the palm oil plant with gas engine capacity of $1000 \mathrm{~kW}$ can generate 2,999 MWh of electricity per year at electricity production cost of $0.103 \$ / \mathrm{kWh}$, resulting in $\mathrm{CO}_{2}$ reduction of 11,109 ton per year, iii) the cassava plant with gas engine capacity of 4,800 kW can generate $13,705 \mathrm{MWh}$ of electricity per year at electricity production cost of $0.105 \$ / \mathrm{kWh}$, resulting in $\mathrm{CO}_{2}$ reduction of 93,854 ton per year, and iv) the swine farm with gas engine capacity of $480 \mathrm{~kW}$ can generate $2,736 \mathrm{MWh}$ of electricity per year at electricity production cost of $0.097 \$ / \mathrm{kWh}$, resulting in $\mathrm{CO}_{2}$ reduction of 23,500 ton per year. Electricity generation from different sources is shown in Table 5 .

Table 5. Summation of electricity generation from different organic waste sources.

\begin{tabular}{lcccc}
\hline Item & Landfill & Palm Oil Plant & Cassava Plant & Swine Farm \\
\hline Gas engine capacity $(\mathrm{kW})$ & 3,000 & 1,000 & 4,800 & 480 \\
Electricity generation $(\mathrm{MWh} / \mathrm{yr}))$ & 13,492 & 2,999 & 13,705 & 2,736 \\
Electricity efficiency $(\%)$ & 40 & 38 & 38 & 40 \\
Levelized electricity cost $(\$ / \mathrm{kWh})$ & 0.115 & 0.103 & 0.105 & 0.097 \\
$\mathrm{CO}_{2}$ reduction potential (ton/yr) & 60,532 & 11,109 & 93,854 & 23,500 \\
\hline
\end{tabular}

Normalized $\mathrm{CO}_{2}$ reduction potential is shown in Fig. 3. The electricity generated from wastewater, its cost in cassava plant is the highest when compared to the palm oil plant, and swine farm because it uses the expensive technology with the type of up-flow anaerobic sludge blanket (UASB) system, an anaerobic bioreactor technology developed originally in Europe. Howeverthe project does not operate withits maximum capacity in the first phase. The electricity cost in other study, such as case of Ghana with the results showed that the cost of incineration plant with energy recovery is the most sensitive to discount variations with almost $\$ 0.200 / \mathrm{kWh}$ power at $15 \%$ discount while that of landfill power plantwith already existing engineered landfill site emerged the least sensitive with $\$ 0.046 / \mathrm{kWh}$ electricity generated at the same rate [9].

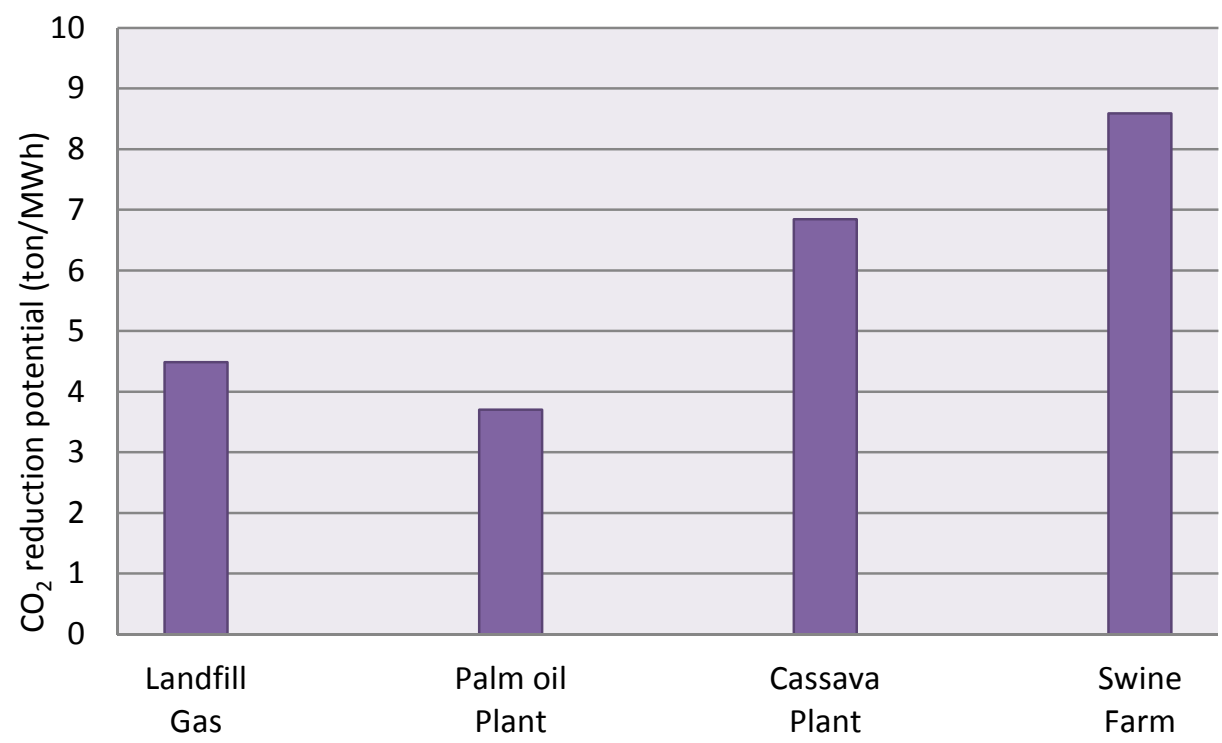

Fig. 3. Carbon dioxide reduction potential of electricity generation from organic waste in Thailand.

\section{Renewable Investment Incentives}

The most desirable and common supporting policy to renewable energy is the feed-in tariffs mechanism that sets the obligation to the utility to purchase the electricity produced RE from the areas of operation. In Thailand, the development of Thailand's adder programis initiated since 2007. The adder, or premium price 
is an additional payment to renewable energy generators on top of the normal prices that power producers would receive when selling electricity to the power utilities. The adder price has been given for landfill gas projects was $\$ 0.083 / \mathrm{kWh}$ of purchased electricity while the price given to biogas projects was $\$ 0.017 / \mathrm{kWh}$, for installed capacity of $1 \mathrm{MW}$ or below; and the price was $\$ 0.010 / \mathrm{kWh}$, for installed capacity of larger than $1 \mathrm{MW}$. This adder price was given to these projects for 7 years. However, subsidiary will be changed to the new scheme of feed-in tariffs price. A project wishing to participate in the conversion to the feed-in tariffs system must lodge an application requesting theEnergy Regulatory Commission (ERC) and apply for a new power purchase agreements (PPA) within 31 March 2015. A single fixed feed-in tariff may provide greater financial returns than the price payable under an adder rate. The feed-in price given to landfill gas projects will be at $5.60 \mathrm{baht} / \mathrm{kWh}(\$ 0.17 / \mathrm{kWh})$ of generated electricity. The subsidiary period for landfill gas projects is 10 years. The feed-in price given to biogas projects will be at $5.60 \mathrm{baht} / \mathrm{kWh}(\$ 0.17 / \mathrm{kWh})$ of generated electricity. The subsidiary period for landfill gas projects is 10 years. Thegenerated electricity from wastewater-based projects, its feed-in price is $3.76 \mathrm{baht} / \mathrm{kWh}(\$ 0.114 / \mathrm{kWh})$ for 20 years subsidiary period, together with it extra premium price of $0.5 \mathrm{baht} / \mathrm{kWh}(\$ 0.015 / \mathrm{kWh})$ within 8 years subsidiary. The projectsin landfill gas and in biogas projects have legiblepotential toregister as a CDM project activity. The selling of annual carbon credits helps the private sectors more profitable and receiving higher return of investments. The carbon credits, CER at the present price is approximately with $8 \mathrm{EUR} /$ ton $\mathrm{CO}_{2}$.

\section{Conclusion}

This study investigated electricity which generated from organic waste in different technologies in Thailand. The results found that the cost of electricity varied from 0.097 to $0.115 \$ / \mathrm{kWh}$ and the potential of $\mathrm{CO}_{2}$ reduction is varied from 3.70 to 8.58 ton- $\mathrm{CO}_{2}$ per MWh electricity production from organic waste in palm oil plant, landfill gas, cassava plant, and in swine farm. In order to meet this high demand while ensuring the sustainable development of power generation, the Thai government through the Provincial Electricity Authority (PEA) of Thailand has being encouraged the electricity production from different renewable energy sources including in Landfill gas, and from organic wastewater or biogas. Energy from waste is therefore having its potential reduction in $\mathrm{CO}_{2}$ emissions. The new scheme of subsidiary in terms of feed-in tariffs in purchasing electricity from renewable energy will enhance private sectors in long term investment feasibility.

\section{References}

[1] Electricity Generating Authority of Thailand, "Thailand power supply and peak demand 19692013,"Bangkok, Thailand, Electricity Generating Authority of Thailand, 2013.

[2] Department of Alternative Energy Development and Efficiency, "Thailand alternative energy situation 2012," Bangkok, Thailand, Department of Alternative Energy Development and Efficiency. Ministry of Energy, 2012.

[3] UNFCCC. (2015).Clean Development Mechanism methodology. Available at https://cdm.unfccc.int/methodologies/index.html

[4] M. Kharseh, M. Al-Khawaja, F. Hassani, "Utilization of oil wells for electricity generation: Performance and economics," Energy, vol. 90, pp. 910-915, 2015.

[5] CADDET, IEA. (2000). Centre for Analysis and Dissemination of Demonstrated Energy Technologies. Batch Anaerobic Digestion of Green Waste in a BIOCEL Converter, Technical Brochure no. 134. Available at http://attfile.konetic.or.kr/konetic/xml/use/31C3A0300618.pdf (accessed on 8.08.15).

[6] D. Sengupta, and R. W. Pike, "Chemicals from biomass: Integrating bioprocesses into chemical production complexes for sustainable development,"CRC, Press, Boca Raton, FL., 2012.

[7] NETL. (2014) Gasifier. Available at: https://netl.doe.gov/research/Coal/energy-systems/gasification/gasifipedia/types-gasifier

[8] U.S. EPA. (1996). AP 42, Fifth Edition. Compilation of Air Pollutant Emission Factors, Volume 1: Stationary Point and Area Sources, Section 2.1. Refuse Combustion. Office of Air Quality Planning and Standards, Research Triangle Park, NC.

[9] C. Ofori-Boateng, K.Teong Lee, and M. Mensah, "The prospects of electricity generation from municipal solid waste (MSW) in Ghana: A better waste management option," Fuel Processing Technology, vol. 110, pp. 94-102, 2013. 